\title{
The Analysis of Mutual Funds' Performance in Lithuanian Financial Market
}

\author{
Povilas Vyšniauskas ${ }^{1}$, Viktorija Stasytyte ${ }^{2}$ \\ Department of Finance Engineering, Faculty of Business Management, \\ Vilnius Gediminas Technical University, Vilnius, Lithuania

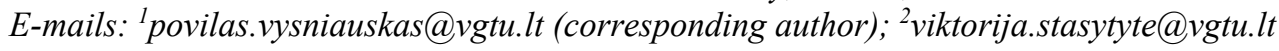

Received 14 February 2017; accepted 10 April 2017

\begin{abstract}
This Article examines performance of mutual funds, which are available for Lithuanian investors in Lithuanian financial market to invest in. Lithuanian mutual funds market is very new comparing with the global financial markets. Majority of mutual funds in Lithuania are imported by Scandinavian banks as well as internationally managed, only few mutual funds are managed in Lithuania. The analysis includes Lithuanian and non-Lithuanian mutual funds in Lithuanian financial market. Period from 2008 to 2016 is analysed in order to get significant results. This study aims to analyse the performances of mutual funds in Lithuanian market on the basis of risk and return criteria using different tools such as Sharpe ratio, Treynor ratio, and Jensen Alpha and others. Also there is analysed variation of these performance measures during selected time period, and discovered periods, when mutual funds perform above and below than market indices.
\end{abstract}

Keywords: Financial markets, Mutual funds, performance evaluation, performance analysis, risk, return.

JEL Classification: G12, G20, G24, G23, G24.

Conference topic: Contemporary Financial Management.

\section{Introduction}

Mutual funds are defined as the collective investment schemes that are professionally managed to collect excess funds from investors for being invested in securities in general. The first mutual fund was developed in Netherlands in the 18th century. Mutual fund is an investment company which collects money form the investors and invest their money in the financial market. It also can by defined as a trust that pools the savings of number investors towards common financial goal.

Mutual fund is the most suitable investment product for the common person as it offers an opportunity to invest in a diversified, professionally managed portfolio at a relatively low costs. There are near 80 thousand mutual funds globally. Net assets invested in mutual funds are 34.89 trillion Eur. Looking at these numbers we can say that mutual funds are an ultimate investment vehicles. People choose mutual funds as an investment to invest in because of its diversification, professional management, reasonability, liquidity and convenience (Gomatheeswaran, Rajan 2013).

Dalbar in its annual Quantitative Analysis of Investor Behavior (QAIB) has measured the results, who much investors who invest in mutual funds earn. The results constantly show that the average investor earns less, in many cases much less than mutual fund performance reports would suggest. The analysis shows that in 2015 the average equity mutual fund investor underperformed the index by a margin of $3.66 \%$. While market made incremental gains of $1.38 \%$, the average equity investor suffered loss of $-2.28 \%$. This reason pushes to the deeper analysis of mutual fund performance (Dalbar 2016).

The aim of this article is to find differences in mutual fund performance between good and bad mutual funds.

The objet: Mutual funds.

Tasks:

- To analyse scientific literature about the performance evaluation of mutual funds.

- To create a data base of mutual funds available for Lithuanian investors.

- To analyse performance of these mutual funds using risk-adjusted portfolio performance measures.

(C) 2017 P. Vyšniauskas, V. Stasytyte. Published by VGTU Press. This is an open-access article distributed under the terms of the Creative Commons Attribution (CC BY 4.0) License, which permits unrestricted use, distribution, and reproduction in any medium, provided the original author and source are credited. 


\section{Development of portfolio performance measures}

Performance evaluation is a process that encompasses performance measurement. Performance measurement involves an approach of accurately calculating rate of return of any investment strategy of a fund over the evaluation period by considering risks undertaken. On the other hand, performance evaluation results commensurates with the fund's investment objective and compares the returns with the appropriate benchmark (Babar 2016).

In this section there is provided a review of the methods for measuring performance of professionally managed portfolios or simply called mutual funds. Before the Modern Portfolio Theory was established, investment portfolio of mutual fund performance was evaluated almost entirely on the basis of the rate of return. Back before 1960s, scientific literature has witnessed an explosion of new investment portfolio performance measures. Developments of portfolio theory in the early 1960s enabled investors to quantify risk in terms of return. But still these two measures were interpreted separately and there were not single measure combined risk and return. Friend et al. (1970) grouped portfolios into similar risk classes based on return variance and then compared the rates of return of portfolios within different risk classes.

Traditional performance measures are strongly influenced by the Capital Asset Pricing Model developed by Sharpe (1964). The capital asset pricing model (CAPM) extends capital market theory in a way that allows to evaluate the risk-return trade-off for diversified portfolios and individual securities. The first composite portfolio performance measure that included risk was developed by Treynor (1965). For the risk identification due to market fluctuations, he introduced portfolio beta, which shows the return fluctuations of a managed portfolio and market. Similar to Treynor performance measure is Sharpe performance measure or simply Sharpe index developed by Sharpe (1966). Sharpe index takes into account return and unsystematic risk. The difference between Trenor and Sharpe measures is risk. Treynor uses systematic risk beta coefficient and Sharpe uses standard deviation as risk measure. He developed reward to volatility concept for evaluation of mutual fund performance (Khan et al. 2016). Sharpe index seeks to measure the total risk of the portfolio by using standard deviation of the return than considering only the systematic risk summarized by beta. Jensen (1968) created portfolio performance measure based on Capital Asset Price Model (CAPM) which calculates the expected one-period return on any security or portfolio. Jensen's Alpha is the most widely used measure of risk adjusted performance. If alpha is positive the manager earns an abnormal return relative to the alternative of holding the benchmark portfolio strategy. A positive alpha connotes superior stock selection skills of the fund manager. Evaluating the performance of 115 open-end mutual funds over the period 1945-1964, it was found that, on an average, investment managers possess poor stock selection skills (Babar 2016).

Jensen's single-factor model is then quickly generalized to include more factors so as to enhance estimation accuracy by many researchers. More recently, Fama and French (1993) introduced a three-factor model, and Carhart (1997) adds a measurement of momentum as the fourth factor to pinpoint the effect of persistence encompassing irrationality (Gang, Qian 2016). Closely related to the ratios just presented is a fourth widely used performance measure is the Information Ratio (IR). The information ratio is a measure that seeks to summarize in a single number the meanvariance properties of an active portfolio. It builds on the Markowitz mean-variance paradigm, which states that the mean and variance (or mean and standard deviation) of returns are sufficient statistics for characterizing an investment portfolio. Calculation of an information ratio is based on the standard statistical formulas for the mean and standard deviation (Goodwin 1998). Table 1 compares composite portfolio performance measures which are described above.

Table 1. Comparing the portfolio performance measures (Source: Reilly, Brown 2012)

\begin{tabular}{|c|c|c|c|}
\hline $\begin{array}{l}\text { Performance } \\
\text { Measure }\end{array}$ & Risk-Adjustment Measure & Advantages & Disadvantages \\
\hline $\begin{array}{l}\text { Treynor Ratio } \\
\text { (T) }\end{array}$ & $\begin{array}{l}\text { Portfolio beta relative to mar- } \\
\text { ket index proxy }\end{array}$ & $\begin{array}{l}\text { - Simple and intuitive "benefit- } \\
\text { cost" comparison of the risk-re- } \\
\text { turn trade-off } \\
\text { - Linked conceptually to the SML } \\
\text { and capital market theory } \\
\text { - Relatively simple to calculate and } \\
\text { widely used in practice }\end{array}$ & $\begin{array}{l}\text { - Permits only relative assess- } \\
\text { ments of performance of dif- } \\
\text { ferent portfolios } \\
\text { - Difficult to interpret and as- } \\
\text { sess statistical significance } \\
\text { - Ignores unsystematic risk in a } \\
\text { portfolio }\end{array}$ \\
\hline $\begin{array}{l}\text { Sharpe Ratio } \\
\text { (S) }\end{array}$ & $\begin{array}{l}\text { (1) Standard deviation of to- } \\
\text { tal portfolio return; or } \\
\text { (2) Standard deviation of } \\
\text { portfolio return in excess } \\
\text { of risk-free rate }\end{array}$ & $\begin{array}{l}\text { - Simple and intuitive "benefit- } \\
\text { cost" comparison of the risk-re- } \\
\text { turn trade-off } \\
\text { - Linked conceptually to the CML } \\
\text { and capital market theory } \\
\text { - Simplest to calculate and widely } \\
\text { used in practice }\end{array}$ & $\begin{array}{l}\text { - Permits only relative assess- } \\
\text { ments of performance of dif- } \\
\text { ferent portfolios } \\
\text { - Difficult to interpret and as- } \\
\text { sess statistical significance } \\
\text { - Ignores diversification poten- } \\
\text { tial of portfolio }\end{array}$ \\
\hline
\end{tabular}




\begin{tabular}{|c|c|c|c|}
\hline $\begin{array}{c}\text { Performance } \\
\text { Measure }\end{array}$ & Risk-Adjustment Measure & Advantages & Disadvantages \\
\hline $\begin{array}{l}\text { Jensen's } \\
\text { Alpha }(\alpha)\end{array}$ & $\begin{array}{l}\text { (1) Portfolio beta relative to } \\
\text { market index proxy; or } \\
\text { (2) Portfolio betas relative to } \\
\text { multiple risk factors }\end{array}$ & $\begin{array}{l}\text { - Most rigorous risk-adjustment } \\
\text { process separating systematic and } \\
\text { unsystematic risk components } \\
\text { - Can be adapted to either CAPM } \\
\text { or multifactor models of the risk- } \\
\text { return trade-off } \\
\text { - Intuitive interpretation of meas- } \\
\text { ure that permits statistical signifi- } \\
\text { cance assessment }\end{array}$ & $\begin{array}{l}\text { - More difficult computation re- } \\
\text { quiring formal regression } \\
\text { analysis } \\
\text { - Diversification of portfolio as- } \\
\text { sessed in separate measure } \\
\text { from performance } \\
\text { - Alpha level and significance } \\
\text { can vary greatly depending on } \\
\text { specification of return-gener- } \\
\text { ating model }\end{array}$ \\
\hline $\begin{array}{l}\text { Information } \\
\text { Ratio (IR) }\end{array}$ & $\begin{array}{l}\text { Standard deviation of portfo- } \\
\text { lio return in excess of return } \\
\text { to } \\
\text { style-class benchmark index } \\
\text { (i.e., tracking error) }\end{array}$ & $\begin{array}{l}\text { - Direct comparison of portfolio } \\
\text { performance compared to bench- } \\
\text { mark in investment style class } \\
\text { - Simple and intuitive measure of } \\
\text { the "benefit-cost" trade-off in- } \\
\text { volved with active management } \\
\text { - Flexible design permitting multi- } \\
\text { ple benchmark comparisons }\end{array}$ & $\begin{array}{l}\text { - Permits only relative assess- } \\
\text { ments of performance for dif- } \\
\text { ferent portfolios in a style } \\
\text { class } \\
\text { - Difficult to interpret and as- } \\
\text { sess statistical significance } \\
\text { - Implicitly assumes that portfo- } \\
\text { lio and benchmark have simi- } \\
\text { lar levels of systematic risk }\end{array}$ \\
\hline
\end{tabular}

There are compared main risk-adjusted portfolio performance measurements which are presented in the Table 1 above. Showed advantages and disadvantages of each portfolio performance measure.

Sortino and Price (1994) developed also a risk-adjusted portfolio performance measure, but it differs from previous measures in two ways. First, the Sortino ratio measures portfolio average return in excess of a user-selected minimum acceptable return and second, this measure captures only downside risk of the portfolio. Grinblatt and Titman (1993) developed holdings based portfolio performance measure. Grinblatt-Titman (GR) performance measure shows the manager's ability of security selection, it can be established by how he adjusted these weights. This holdings based ratio has a limitation that it does not controled directly for changes in risk or investment style. In addition, the Grinblatt and Titman benchmarks may not fully account for return anomalies, such as the size, book-to-market, and momentum effects. According to this limitation Daniel et al. (1997) developed an alternative holdings-based measure - Characteristic selectivity (CS) portfolio performance measure. The CS measure uses as a benchmark the return of a portfolio of stocks that is matched to the fund's holdings each quarter along the dimensions of size (market value of equity), book-to-market ratio, and momentum (the prior year return of the stock) (Daniel et al. 1997). Fulkerson (2013) decompose returns into two broad components. The trading component measures additional return gained or lost through changing the portfolio and captures the value created the short run anticipation of returns. The selection component measures how long-term holdings would have created value. A manager with selection ability creates value by tending to hold stocks that outperform over a longer period. The selection and trading components are not mutually exclusive and a fund may benefit from both.

Over the years, mutual funds have attracted a lot of attention of academicians, researchers and investors and have been a focus of research. It has also led to the development of various measures and models to evaluate their performance (Ayaluru 2016).

\section{Data and descriptive statistics}

For the analysis there are taken mutual funds which are available to invest in Lithuanian financial market. There are selected 63 mutual funds which invest globally or in different regions. Only stock mutual funds are analyzed, because other mutual fund categories requires to use different evaluation methods. For the analysis are used 2008-01-01 - 201612-31 period historical data which are taken form Bloomberg Terminal. Table 2 represents key statistics of selected mutual funds.

As we see in Table 2, statistical results vary very widely. Average growth per period of all selected mutual funds is $38.15 \%$, but it vary form minimum value $-41.11 \%$ return per period to $337.09 \%$ return during the analyzed period. Also other key statistics like annual growth rate, mean monthly return, excess return are calculated. Risk factors: standard deviation and ratios: Traynor, Sharpe and Alpha ratios are represented.

To evaluate risk-adjusted mutual fund performance, it is necessary to have some type of nominal performance benchmark. The benchmark problem in global capital markets, consider how individual measures of risk change when the world equity market is employed as the market portfolio. For the benchmark problem are selected MSCI family benchmarks which are widely used in practice. MSCI market cap weighted indexes are among the most respected and widely used benchmarks in the financial industry. 
Table 2. Data and descriptive statistics of mutual funds (Source: created by authors)

\begin{tabular}{|c|c|c|c|c|c|c|c|c|c|c|}
\hline $\begin{array}{l}\text { Time } \\
\text { period }\end{array}$ & $\begin{array}{l}\text { Number } \\
\text { of Funds }\end{array}$ & \multicolumn{4}{|c|}{ Return } & \multicolumn{2}{|c|}{ Risk } & \multicolumn{3}{|c|}{ Ratio } \\
\hline $\begin{array}{c}2008-01-01 \\
- \\
2016-12-31\end{array}$ & 63 & $\begin{array}{l}\text { Growth } \\
\text { per } \\
\text { Period }\end{array}$ & $\begin{array}{l}\text { Annual } \\
\text { Growth }\end{array}$ & $\begin{array}{l}\text { Mean } \\
\text { Monthly } \\
\text { Return }\end{array}$ & $\begin{array}{l}\text { Excess } \\
\text { Return }\end{array}$ & $\begin{array}{c}\text { Standard } \\
\text { Deviation }\end{array}$ & Beta & Treynor & Sherpe & Alpha \\
\hline \multicolumn{2}{|c|}{ Average } & $38.15 \%$ & $2.72 \%$ & $0.4 \%$ & $0.54 \%$ & $5.86 \%$ & 0.899 & 0.007 & 0.008 & 0.002 \\
\hline & Max & $337.09 \%$ & $17.81 \%$ & $1.58 \%$ & $7.89 \%$ & $9.64 \%$ & 1.398 & 0.477 & 0.185 & 0.007 \\
\hline & Min & $-41.11 \%$ & $-5.77 \%$ & $-0.29 \%$ & $-6.57 \%$ & $3.22 \%$ & 0.008 & -0.012 & -0.135 & -0.005 \\
\hline
\end{tabular}

\section{Methodology}

For the mutual fund performance measurement are selected the most popular and widely usable risk-adjusted portfolio performance ratios. Risk-adjusted ratios quantify the risk volatility of stock and represent that risk with simple numbers (Vyšniauskas, Rutkauskas 2014).

Treynor ratio

A higher value of the Treynor ratio suggests better performance. Unlike the Sharpe ratio, the excess return is normalized relative to the systematic risk or beta, not the total risk or volatility. The slope of this portfolio possibility line (designated $T$ ) is equal to:

$$
T_{i}=\frac{\overline{R_{i}}-\overline{R F R}}{\beta_{i}},
$$

where: $\overline{R_{i}}$ - the average rate of return for portfolio $i$ during a specified time period, $\overline{R F T}$ - the average rate of return on a risk-free investment during the same period, $\beta_{i}$ - the slope of the fund's characteristic line during that time period. Sharpe ratio

The Sharpe ratio measures the degree to which a portfolio is able to yield a return in excess of the risk-free return to cash, per unit of risk. The Sharpe measure of portfolio performance (designated $S$ ) is stated as follows:

$$
S_{i}=\frac{\overline{R_{i}}-\overline{R F R}}{\sigma_{i}},
$$

where: $\overline{R_{i}}$ - the average rate of return for portfolio $i$ during a specified time period, $\overline{R F T}$ - the average rate of return on a risk-free investment during the same period, $\sigma_{i}$ - the standard deviation of the rate of return for portfolio $i$ during the time period.

Jensen's Alpha

The Jensen's alpha measures a fund's outperformance through the difference between the return on the mutual fund and the return on the single-factor benchmark according to an estimating CAPM. The single-beta CAPM Jensen alpha measure is the intercept from the regression of portfolio excess returns on the market portfolio excess returns:

$$
R_{j t}-R F R_{t}=\alpha_{j}+\beta_{j}\left[R_{m t}-R F R_{t}\right]+e_{j t},
$$

where: $R_{j t}$ - the mutual fund portfolio return in month $\mathrm{t}, R F R_{t}-$ the risk free return in month $\mathrm{t}, R_{m t}-$ the return on the market portfolio in month t, $e_{j t}$ - the white noise error term, and $\beta_{j}$ - the regression's intercept and slope (beta risk) coefficient.

A majority of the academic studies use alpha as the main performance indicator, but we believe excess return is more relevant to financial planners when they advise their retail investors to invest in mutual funds. Normally, alpha is the measure of excess return of a fund above and beyond the return explained by the market excess return before expenses. Mathematically, excess return can be computed by using the following equation:

$$
E R_{i t}=R_{i t}-R M_{t}-E X P_{i t},
$$

where: $E R_{i t}$ - the excess return of fund $i$ at time t, $R_{i t}$ - the monthly return earned by fund $i$ at time $\mathrm{t}, R M_{t}-$ the benchmark's monthly return at time t, $E X P_{i t}$ - the expenses paid to the fund $i$ 's management at time $\mathrm{t}$. 


\section{Empirical Results}

For deeper analysis, how performance ratios vary yearly, are selected 10 the best and the worst mutual funds which are represented in Tables 3 and 4 below.

Table 3. 10 the best and the worst mutual funds in terms of annual return (Source: created by authors)

\begin{tabular}{ll|lc}
\hline \multicolumn{1}{c}{ Best 10 } & \multicolumn{2}{c}{ Annual return } & \multicolumn{2}{c}{ Worst 10} \\
\hline Franklin Biotechnology discovery & $17.81 \%$ & Swedbank Russian Equity & $-5.77 \%$ \\
T. Rowe US Smaller Companies & $13.76 \%$ & Danske Russia Small Cap & $-5.26 \%$ \\
Danske Sustainability Equity & $11.00 \%$ & Julius Baer Africa Focus & $-4.99 \%$ \\
T. Rowe US Blue Chip & $10.82 \%$ & Julius Baer Eastern Europe Focus & $-4.71 \%$ \\
T. Rowe US Large Cap Value & $10.10 \%$ & East Capital Eastern European & $-4.52 \%$ \\
Nordea Nordic Equity Small Cap & $9.92 \%$ & East Capital Russian Fund & $-4.00 \%$ \\
Prudentis Global Value & $9.40 \%$ & Danske Eastern Europe Convergence & $-3.84 \%$ \\
Julius Baer US Leading Stock & $8.67 \%$ & SEB Eastern Europe ex Russia & $-3.70 \%$ \\
Danske North America Equity & $8.07 \%$ & Templeton BRICK & $-3.28 \%$ \\
Julius Baer Japan Stock & $7.35 \%$ & East Capital Baltic Fund & $-2.81 \%$ \\
\hline
\end{tabular}

Table 4. 10 the best and the worst mutual funds in terms of annual excess return (Source: created by authors)

\begin{tabular}{ll|lc}
\hline \multicolumn{2}{c}{ Best 10 } & \multicolumn{2}{c}{ Wnnul Excess Return 10} \\
\hline Danske Finnish Equity & $7.89 \%$ & Julius Baer Africa Focus & $-6.57 \%$ \\
Nordea Nordic Equity Small Cap & $7.41 \%$ & East Capital Baltic Fund & $-6.38 \%$ \\
Nordea Global Stable Equity Euro Hedged & $6.65 \%$ & SEB US All Cap & $-4.95 \%$ \\
\hline Nordea Norwegian Equity & $5.96 \%$ & Nordea North America Value & $-4.45 \%$ \\
Franklin European growth & $5.89 \%$ & Julius Baer US Value Stock & $-4.11 \%$ \\
SEB Russia & $5.06 \%$ & Orion OMX Baltic Benchmark & $-4.05 \%$ \\
Julius Baer Europe Small Mid Cap & $4.89 \%$ & Danske India fund & $-3.87 \%$ \\
Danske Sustainability Equity & $4.58 \%$ & Julius Baer Global Equity Income & $-3.31 \%$ \\
T. Rowe Middle East and Africa & $4.52 \%$ & SEB Global & $-2.90 \%$ \\
Franklin Indian Fund & $4.50 \%$ & Franklin Japan Fund & $-2.61 \%$ \\
\hline
\end{tabular}

Table 3 and 4 represent 10 the best and the worst mutual funds in terms of annual returns and annual excess returns respectively. Annual return of the best mutual funds wary from $7.35 \%$ to $17.81 \%$. The best return generated Franklin Biotechnology fund. Biotechnology sector had the higest growth of all sectiors during last decade. But this fund did not show such a good results using annual excess return. This means that this fund didn't show superior performance against its index. The worst performing mutual fund in both categories generated negative annual and excess returns respectively. Negative annual return shows, that during analyzed period, fund destroyed its value.

Results how performance ratios changed its values during different time periods from 2008 to 2016 are presented below. For this analysis also where selected 10 the best and the worst mutual funds in terms of annual return and annual excess return. 
Table 5. Annual results of performance ratios of the best 10 annual return mutual funds (Source: created by authors)

\begin{tabular}{|c|c|c|c|c|c|c|c|c|c|}
\hline \multicolumn{10}{|c|}{ Treynor } \\
\hline & 2008 & 2009 & 2010 & 2011 & 2012 & 2013 & 2014 & 2015 & 2016 \\
\hline Average & -0.036 & 0.009 & 0.017 & -0.006 & 0.003 & 0.079 & 0.013 & 0.012 & 0.018 \\
\hline Min & -0.060 & -0.028 & 0.010 & -0.039 & -0.028 & 0.009 & 0.001 & 0.005 & -0.010 \\
\hline Max & -0.015 & 0.043 & 0.043 & 0.009 & 0.018 & 0.621 & 0.033 & 0.025 & 0.122 \\
\hline \multicolumn{10}{|c|}{ Sharpe } \\
\hline & 2008 & 2009 & 2010 & 2011 & 2012 & 2013 & 2014 & 2015 & 2016 \\
\hline Average & -0.545 & 0.215 & 0.311 & -0.069 & 0.196 & 0.591 & 0.536 & 0.183 & 0.301 \\
\hline Min & -0.732 & -0.062 & 0.072 & -0.305 & -0.021 & 0.374 & 0.011 & -0.170 & -0.109 \\
\hline Max & -0.123 & 0.526 & 0.421 & 0.197 & 0.339 & 0.744 & 1.208 & 0.448 & 0.874 \\
\hline \multicolumn{10}{|c|}{ Alpha } \\
\hline & 2008 & 2009 & 2010 & 2011 & 2012 & 2013 & 2014 & 2015 & 2016 \\
\hline Average & 0.000 & 0.007 & 0.003 & 0.000 & 0.001 & 0.003 & 0.001 & 0.003 & 0.005 \\
\hline Min & -0.019 & -0.005 & 0.000 & -0.019 & -0.005 & -0.006 & -0.008 & -0.004 & -0.010 \\
\hline Max & 0.012 & 0.019 & 0.011 & 0.009 & 0.007 & 0.014 & 0.011 & 0.013 & 0.023 \\
\hline
\end{tabular}

Table 5 shows how performance evaluation ratios changes during different time period of the best mutual funds in terms of annual return. The worst results were during 2008, when markets suffered from financial crisis. Sharpe and Treynor ratios where negative during this period. It means that fund managers didn't manage performance against systematic and unsystematic risk. Alpha ratio which shows how much value was added by manager was negative or around zero during analyzed period.

The results of the worst mutual funds in terms of annual returns are represented below.

Table 6. Annual results of performance ratios of the worst 10 annual return mutual funds (Source: created by authors)

\begin{tabular}{|c|c|c|c|c|c|c|c|c|c|}
\hline \multicolumn{10}{|c|}{ Treynor } \\
\hline & 2008 & 2009 & 2010 & 2011 & 2012 & 2013 & 2014 & 2015 & 2016 \\
\hline Average & -0.093 & 0.058 & 0.352 & -0.036 & 0.009 & -0.001 & -0.031 & -0.002 & 0.031 \\
\hline Min & -0.127 & 0.013 & 0.008 & -0.060 & -0.006 & -0.013 & -0.073 & -0.033 & 0.006 \\
\hline Max & -0.060 & 0.112 & 3.316 & -0.027 & 0.019 & 0.023 & 0.002 & 0.028 & 0.053 \\
\hline \multicolumn{10}{|c|}{ Sharpe } \\
\hline & 2008 & 2009 & 2010 & 2011 & 2012 & 2013 & 2014 & 2015 & 2016 \\
\hline Average & -0.815 & 0.493 & 0.370 & -0.497 & 0.155 & -0.066 & -0.292 & -0.023 & 0.503 \\
\hline Min & -0.924 & 0.125 & 0.148 & -0.782 & -0.044 & -0.334 & -0.610 & -0.433 & 0.054 \\
\hline Max & -0.689 & 0.718 & 0.665 & -0.323 & 0.397 & 0.172 & 0.044 & 0.259 & 1.049 \\
\hline \multicolumn{10}{|c|}{ Alpha } \\
\hline & 2008 & 2009 & 2010 & 2011 & 2012 & 2013 & 2014 & 2015 & 2016 \\
\hline Average & -0.016 & 0.016 & 0.009 & -0.010 & 0.001 & 0.000 & -0.006 & 0.001 & 0.009 \\
\hline Min & -0.038 & -0.005 & 0.003 & -0.022 & -0.005 & -0.017 & -0.023 & -0.029 & -0.004 \\
\hline Max & -0.002 & 0.040 & 0.018 & -0.002 & 0.009 & 0.009 & 0.005 & 0.014 & 0.023 \\
\hline
\end{tabular}

The situation of the worst performing mutual fund in terms of annual return is very similar to results of the best performing mutual funds in terms of annual return. There were some periods when the worst performing mutual funds had better performance evaluation ratios than the best performing mutual funds. It means that there is no pattern between annual returns and risk-adjusted portfolio performance ratios.

The same analysis of risk-adjusted portfolio performance ratios is made with the best and the worst performing mutual funds in terms of excess return. The results are shown in the tables below. 
Table 7. Annual results of performance ratios of the best 10 excess return mutual funds (Source: created by authors)

\begin{tabular}{cccccccccc}
\hline & \multicolumn{7}{c}{ Treynor } \\
\hline & 2008 & 2009 & 2010 & 2011 & 2012 & 2013 & 2014 & 2015 & 2016 \\
\hline Average & -0.052 & 0.032 & 0.022 & -0.018 & -0.021 & 0.030 & -0.014 & 0.050 & 0.045 \\
Min & -0.080 & 0.006 & -0.007 & -0.039 & -0.333 & -0.008 & -0.304 & -0.062 & 0.001 \\
Max & 0.018 & 0.056 & 0.076 & 0.002 & 0.025 & 0.116 & 0.052 & 0.474 & 0.344 \\
\hline & & \multicolumn{7}{c}{ Sharpe } \\
\hline Average & 0.907 & 0.360 & 0.760 & -0.285 & 0.270 & 0.702 & 0.084 & 0.173 & 0.345 \\
Min & -0.806 & 0.055 & -0.118 & -0.557 & 0.045 & -0.148 & -1.826 & -0.170 & 0.005 \\
Max & 1.213 & 0.652 & 4.951 & 0.030 & 0.527 & 2.535 & 0.884 & 0.448 & 1.649 \\
\hline & & & & & & & & \\
\hline Average & 0.003 & 0.012 & 0.006 & -0.001 & 0.006 & 0.010 & -0.008 & 0.000 & 0.013 \\
Min & -0.019 & -0.001 & 0.000 & -0.009 & -0.002 & 0.002 & -0.126 & -0.034 & 0.000 \\
Max & 0.023 & 0.028 & 0.013 & 0.011 & 0.030 & 0.030 & 0.018 & 0.013 & 0.072 \\
\hline
\end{tabular}

Table 7 shows how performance evaluation ratios changes during different time period of the best mutual funds in terms of excess return. Comparing the results with the results of the best mutual funds in terms of annual return. Performance evaluation ratios of mutual funds in terms of excess return have the greater values. It means that excess return better represent how manager manage mutual funds. Annual return represents market of specific region in which mutual fund invests. The main difference is between Sharpe ratios. Mutual funds with better excess return also have higher values of Sharpe ratios. Average Alpha ratio shows slightly better results too. The results of the worst excess return mutual funds are given in the table below.

Table 8. Annual results of performance ratios of the worst 10 excess return mutual funds (Source: created by authors)

\begin{tabular}{|c|c|c|c|c|c|c|c|c|c|}
\hline \multicolumn{10}{|c|}{ Treynor } \\
\hline & 2008 & 2009 & 2010 & 2011 & 2012 & 2013 & 2014 & 2015 & 2016 \\
\hline Average & -0.066 & 0.016 & 0.021 & -0.016 & 0.037 & -0.006 & 0.060 & 0.082 & 0.050 \\
\hline Min & -0.116 & -0.025 & 0.004 & -0.055 & -0.009 & -0.066 & -0.024 & -0.044 & -0.272 \\
\hline Max & -0.034 & 0.058 & 0.066 & 0.002 & 0.312 & 0.021 & 0.498 & 0.838 & 0.794 \\
\hline \multicolumn{10}{|c|}{ Sharpe } \\
\hline & 2008 & 2009 & 2010 & 2011 & 2012 & 2013 & 2014 & 2015 & 2016 \\
\hline Average & -0.712 & 0.152 & 0.264 & -0.391 & 0.030 & 0.416 & 0.058 & -0.610 & 0.091 \\
\hline Min & -1.141 & -1.109 & -0.090 & -1.210 & -1.172 & -0.167 & -2.582 & -0.852 & -0.695 \\
\hline Max & 0.559 & 0.881 & 0.602 & 0.292 & 0.806 & 1.457 & 1.340 & 0.361 & 0.644 \\
\hline \multicolumn{10}{|c|}{ Alpha } \\
\hline & 2008 & 2009 & 2010 & 2011 & 2012 & 2013 & 2014 & 2015 & 2016 \\
\hline Average & -0.003 & -0.002 & 0.001 & -0.007 & -0.003 & 0.007 & 0.001 & -0.006 & -0.005 \\
\hline Min & 0.037 & 0.022 & 0.011 & 0.002 & 0.010 & 0.050 & 0.032 & 0.010 & 0.017 \\
\hline Max & -0.034 & 0.058 & 0.066 & 0.002 & 0.312 & 0.021 & 0.498 & 0.838 & 0.794 \\
\hline
\end{tabular}

Table 8 represents results of annual risk-adjusted portfolio performance ratios of the mutual funds with the lowest excess return. Majority of Treynor and Sharpe ratios during different time periods are negative, itshows that these funds are not able to manage systematic and unsystematic risk. Alpha ratio did not give any useful information about the added value by fund manager. It means that returns are generated by market, not by managers. 


\section{Conclusions}

Lithuanian financial market is very new comparing with Western European or American financial market. For this reason majority of mutual funds are available in Lithuanian market are managed internationally by international banks which operate in Lithuania and have the largest market share.

The most popular and widely used risk-adjusted portfolio ratios such as Treynor, Sharpe and Alpha ratios are based on Capital Asset Price Model (CAPM) theory developed by William Sharpe. Sharpe and Treynor ratios are very similar, differs only risk factors. Treynor ratio uses systematic risk - beta coefficient, Sharpe ratio uses unsystematic risk - standard deviation. This is why there is recommended to use Treynor and Sharpe ratios together. Alpha represents how much value is added by fund manager.

The major problem in performance evaluation of mutual funds is to select exact benchmark, because using wrong benchmark, the results of performance ratios will by useless.

The performance ratios gave better results using mutual funds grouped by excess return than annual return. But it doesn't mean that annual returns are useless. Annual returns shows how much value was generated by mutual fund in total, and excess return shows how much value was generated against index. In the bear markets excess returns could be superior, but annual returns will be negative.

\section{References}

Ayaluru, M. P. 2016. Performance analysis of mutual funds: selected reliance mutual fund schemes. Parikalpana, KIIT Journal of Management 12(1): 52-62. https://doi.org/10.23862/kiit-parikalpana/2016/v12/i1/133055

Babar, S. 2016. Higher order moments based models to evaluate the performance of mutual funds: Indian evidence, The IUP Journal of Applied Finance 22(3): 64-86.

Carhart, M. M. 1997. On persistence in mutual fund performance, The Journal of Finance 52(1): 57-82. https://doi.org/10.1111/j.1540-6261.1997.tb03808.x

Dalbar, Inc. 2016. Quantitative analysis of investor behavior [online], [cited 02 February 2017]. Available from Internet: http://www.qidllc.com/wp-content/uploads/2016/02/2016-Dalbar-QAIB-Report.pdf

Daniel, K.; Grinblatt M.; Titman S.; Wermers, R. 1997. Measuring mutual fund performance with characteristic-based benchmarks, The Journal of Finance 52(3): 1035-1058. https://doi.org/10.1111/j.1540-6261.1997.tb02724.x

Fama, E. F; French, K. R. 1993. Common risk factors in the returns on stocks and bonds, Journal of Financial Economics 33(1): 3-56. https://doi.org/10.1016/0304-405X(93)90023-5

Friend, I.; Blume, M.; Crockett, J. 1970. Mutual funds and other institutional investors: a new perspective. New York: McGrawHill. 197 p.

Fulkerson, J. A. 2013. Is timing everything? The value of mutual fund manager trades, Financial Management 42(2): $243-261$. https://doi.org/10.1111/fima.12005

Gang, J.; Qian, Z. 2016. Risk-adjusted performance of mutual funds: evidence from China, Emerging Markets Finance \& Trade, 52: 2056-2068. https://doi.org/10.1080/1540496X.2016.1156527

Gomatheeswaran, M.; Rajan, J. 2013. Mutual fund as ultimate investment vehicle, International Refereed Research Journal 2(1): 66-70.

Goodwin, T. H. 1998. The information ratio, Financial Analysts Journal 54(4): 34-43. https://doi.org/10.2469/faj.v54.n4.2196

Grinblatt, M.; Titman, S. 1993. Performance measurement without benchmarks: an examination of mutual fund returns, Journal of Business 66(1): 47-68. https://doi.org/10.1086/296593

Jensen, M. C. 1968. The performance of mutual funds in the period 1945-1964, Journal of Finance 23(2): $389-416$. https://doi.org/10.1111/j.1540-6261.1968.tb00815.x

Khan, K.; Jamil, S. A.; Uddin, M. A. 2016. Performance evaluation of mutual funds in Oman: an investors' perspective, Journal of Business and Retail Management Research (JBRMR) 10(2): 111-118.

Reilly, F. K.; Brown, K. C. 2012. Investment analysis and portfolio management. $10^{\text {th }}$ ed. South-Western, USA. 1058 p.

Sharpe, W. F. 1964. Capital asset prices: a theory of market equilibrium under conditions of risk, Journal of Finance 19(3): 425442. https://doi.org/10.1111/j.1540-6261.1964.tb02865.x

Sharpe, W. F. 1966. Mutual fund performance, Journal of Business 39(1), part 2: 119-138.

Sortino, F. A.; Price, L. N. 1994. Performance measurement in a downside risk framework, Journal of Investing 3(3): 59-65. https://doi.org/10.3905/joi.3.3.59

Treynor, J. L. 1965. How to rate management of investment funds, Harvard Business Review 43(1): 63-75.

Vyšniauskas, P.; Rutkauskas, A. V. 2014. Performance evaluation of investment (mutual) funds, Business: Theory and Practice 15(4): 398-407. 